\title{
DEVELOPMENT OF UKRAINIAN ENTERPRISES IN CRISIS ECONOMY IN BRAND MANAGEMENT SYSTEM
}

\author{
Hanna Maiboroda ${ }^{1}$, Anastasiia Marchuk ${ }^{2}$
}

\begin{abstract}
The purpose of the article is to improve and deepen the theoretical aspects of brand value assessment methods, highlighting their advantages and disadvantages, combining existing techniques for more effective assessment of the enterprise, the practical calculation of the brand value "Kyivhlib" on the example of the Ukrainian enterprise-leader of the baking industry. In the article the theoretical analysis of publications, which considered the main aspects of the brand management system at the enterprises, in particular domestic ones, was carried out. The authors also highlighted the subject of the research, which is the given factors and structural elements of brand identity and value from the side of strategic activities of companies that operate in two Ukrainian markets - the market of milk and dairy products and the market of bakery and bakery products. Methodology. To determine the brand value was chosen one of the enterprises in the bakery industry, located in Kyiv - "Kyivhlib". The calculation was carried out using a combination of methods "Interbrand Model" and the method of royalty based on the data of the public accounts of the enterprise for 2019. Determination of the index of the brand role was carried out by expert method using seven basic criteria (leadership, stability, market, internationality, trends, support, protection). The last step was the calculation of the final brand value, where the brand profit is defined as the product of the intangible profit value and the brand role index. Also to calculate the final brand value, it was necessary to calculate the discounted cash flows over the years of the economic life of the investment. Results. As a result the index of brand role added up to $86 \%$. As for "Kyivhlib" it was determined that the brand multiplier value of 18,8 corresponds to a point estimate of brand strength ( 86 points). The results obtained by using the method based on "Interbrand" model showed that brand value of "Kyivhlib" is at the level of 5093,1 thousand UAH. Due to the fact that this model involves a large number of subjective estimates, the results may differ from the calculations obtained by using other methods and models. Practical implications. The value of the brand affects both the financial aspects of the enterprise and its non-financial side. It is worth noting that the brand is an intangible asset but it provides a real financial result in the form of profit. That is why companies, seeking to gain a leading position in the market, should pay close attention to assessing the brand value and using the obtained data in strategic management.
\end{abstract}

Keywords: brand management, bakery industry, marketing communications, promo calendar, brand multiplier, brand value.

JEL Classification: M21, L17, M31

\section{Introduction}

With competition in the industrial market growing everyyear, the number ofidentical products in a certain price segment is also increasing. All these forces manufacturers to look for new ways to create additional competitive advantages aimed at building consumer loyalty to the brand. At the present stage of economic development, the competitiveness of the enterprise can be assessed

\footnotetext{
Corresponding author

${ }^{1}$ Dmytro Motornyi Tavria State Agrotechnological University, Ukraine.

E-mail: annabritsyna@gmail.com

ORCID: https://orcid.org/0000-0002-8190-0259

${ }^{2}$ Dmytro Motornyi Tavria State Agrotechnological University, Ukraine.

E-mail: marchuk_asya@ukr.net

ORCID: https://orcid.org/0000-0001-9308-6066
}

not only by quantitative indicators but also by the presence of a strong brand, which requires constant work on its improvement and strengthening.

But the lack of a clear idea of the brand as a valuable intangible asset, affecting the economic activity of the enterprise, inability to fully assess its value, objectively leads to the necessity to improve theoretical and practical knowledge about the brand as a whole. Today, there is also a big problem 
of deducting the brand value in accounting and financial reporting. Reporting, in most cases, takes into account only financial indicators, and the role of non-financial is underestimated.

Thus, the assessment of the brand value is an important stage of the company's activity, giving it a competitive advantage in the market, the ability to attract the necessary financial resources, helping to form the optimal capital structure of the enterprise.

Many foreign and domestic theorists and practitioners in the field of marketing have been involved in determining the role of the brand and, in particular, methods of estimating its value. In particular, it is necessary to mention works of Genkinson G., Geyer G.V., Keller K., Gorovoy D. A., Scheuer R., Zborovsky R. V., Kobelev V. N., Korolyuk N. Ya., Petrov I. Yu., Polishchuk T. V., Pyatak T. V., Studinska G. Ya., Kholodny G. O., Shvets O. O.

At the same time, the issue of forming a systematic approach to substantiating the universal method of brand evaluation as a means of increasing the competitiveness of the enterprise, as well as the practical possibility to apply these calculations by manufacturers, remains unclear.

The purpose of the article is to improve and deepen theoretical aspects of brand valuation methods, highlight their advantages and disadvantages, combine existing methods for more effective assessment of the company's activity, calculate brand value on the example of the Ukrainian bakery leader "Kyivkhlib".

\section{Presentation of main material}

Brand management is a branding development management system at the enterprise in order to form a positive opinion of consumers. In the market of milk and dairy products for baby food, from the point of view of marketing, the brand is formed under the influence of many criteria such as emotions, attributes, belonging to society, traditions, etc.

General provisions of a brand development theory were laid by the American scientist K. Keller (Keller, Lehmann, 2006). In his works he focuses on categories "brand" and "branding". In studying differences between a product brand and an enterprise, Keller emphasizes that a set of goods and services is an important tool for managing the marketing complex. This approach to branding allows the company to understand the motivations and needs of consumers. The author also emphasizes that the division of branding into components of "product brand" and "enterprise brand" does not allow further identification of the services role in such a system. After all, by definition, Keller distinguishes the "product brand" as an identifier of quality symbols, responsibility of the manufacturer, risk reduction. At the same time, the "brand of the enterprise" is a competitive advantage and unique values of the enterprise.

In this regard, the scientist G. Henkinson (Hankinson, 2004), studying functionality of the brand, identifies five separate principles of the brand - enterprise management. He determines that an effective brand of the enterprise requires a strong far-sighted leadership, brand-oriented organizational structure, coherence of departments, constant communication between the owners, strong partnerships. That is, Gentinson focuses on the brand management aspects and does not associate it with the marketing activities of the enterprise.

Keller and Lehmann shed light on debating the value of the brand in terms of a consumer opinion (Keller, Lehmann, 2006). According to them, brand management should meet the following tasks: brand positioning, marketing integration, performance evaluation, continuous growth, strategic management.

Management of corporate branding strategy is based on a combination of product and enterprise development strategy, according to scientists S. Seo and S. Jeng. They note that in a crisis, customers will intend to visit outlets more often if the brand value is high and the supermarket or store, or another trade establishment uses a corporate strategy (Seo, Jang, 2013).

Using survey in their study, they have found that a common brand value policy is in demand from consumers more than those who use their own policy, unlike other stores in the same network.

In his further work, Keller strengthens the role of branding in marketing communications through the guidance of the brand pyramid (Keller, 2009). The pyramid includes the following elements: brand significance, effectiveness, image, judgments about the brand and the emotions it evokes. In this regard, Keller states that marketers should "mix and match" different types of marketing communications in order to cover all the elements of the brand listed in the pyramid (Keller, 2009). 
At different times, various theories have been put forward on the impact of marketing communications on the development of enterprise brands. At one time, M. Reid put forward the theory of brand strengthening through integrated marketing communications (Reid, 2002). By his definition, they are connected with strategic management in order to develop and operate a brand. M. Reid defines two types of enterprise results of brand management efficiency through marketing communications: results related to profit (market share, profitability, total income, premium price level) and results related to market impact (brand awareness, customer satisfaction, customer loyalty, trade support).

Economist Manhawaran and others have identified the following factors of brand identity and value from the company's strategic activities. Brand identity is expressed in the following aspects:

1) brand-oriented culture;

2) support of top management;

3) internal marketing orientation.

The value of the brand is manifested in the synergy (interactivity, consistency, complexity) and effectiveness of integrated marketing communications.

According to the authors, the three components of brand identity have a positive effect on brand value, which in turn, depends on the synergy of all elements of marketing communications. Thus, effective brand management is based on a coordinated program of integrated marketing communications.

Studying the problems of brand purposefulness, I. Martin (Stewart \& Martin, 1994) finds that consumers need two types of marketing communications. They receive additional knowledge through them, further influencing their purchasing decisions. The author notes that deeper knowledge gives an opportunity to determine compliance with the needs of the consumer and his ideals. More easily accessible knowledge gives information related to the speed of the purchase response. In this regard, communications that perform advisory functions further enhance the role of the brand for the consumer.

In general, much attention should be paid to aspects of corporate marketing management in the development and implementation of brand management in the enterprise. It is the concepts of the internal culture of the company and the outdoor advertising campaign that will be the basis for the effectiveness of brand development. Corporate marketing research formed the basis for the work of J. Ballmer, who introduced the $6 \mathrm{C}$ and 11P systems. Subsequently, both J. Ballmer and scientist S. Graser determine that marketing is associated with the development of the corporate brand through its inheritance, prediction, feasibility and the structure (Simmons et al., 2010).

In terms of a national brand representation, integrated marketing communications should convey information to the consumer on the following elements:

- sector;

- city of the organization;

- business model;

- strategy;

- nature;

- cleanliness;

- target audience.

These elements form a complex structure of the enterprise, in which all elements must be mutually agreed.

R. Scheuer's research shows (Clark et al., 2016) that not only the complex of marketing communications, but also the experience of the enterprise itself plays an important role in changing the brand on the market. The scientist determines that market experience and marketing communications form a positive consumer opinion in the ratio of 0.85: 0.12: 0.3 (0.3 - other market factors). At the same time, Scheuer claims that without timely marketing communications and due to inconsistencies in information, the brand may be negatively assessed in the market.

Based on the scientific inCerpretations of scientists, we formed the main criteria of brand value (table 1 ).

Today, the issues of online ordering of food products, the possibility to obtain consumer feedback through social networks are relevant. From this point of view, development of Internet technologies gives an opportunity to expand the customer base and strengthen the brand's influence through the fifth element of marketing communications - the Internet marketing.J.Simons (Bell et al., 2004) proposes 4 fundamentals and resources for Internet branding research:

Basis 1: understanding the consumer (data collection on the server site, data collection on the client's site, online services, database). 
Table 1

Structural elements of brand value

\begin{tabular}{|l|l|}
\hline \multicolumn{1}{|c|}{ Element } & \multicolumn{1}{|c|}{ Characteristics } \\
\hline Brand loyalty & - Regular contact \\
& - Advice to your friends and acquaintances \\
& - Positive association with life events \\
\hline \multirow{5}{*}{ Quality perception } & - Constant work on errors \\
& - Fast and high-quality service \\
& - Highly qualified staff \\
& - Visually attractiveness and aesthetics \\
& - Adherence to corporate identity \\
\hline \multirow{5}{*}{ Brand image } & - Value for money \\
& - Availability \\
& - Differentiated image \\
& - Experience \\
& - Comfortable cooperation with other participants in the marketing environment \\
& - Long history of existence \\
\hline Brand recognition & - The first thing that comes to mind \\
& - Lack of analogues at the regional level \\
\hline
\end{tabular}

Source: developed by the authors based on (Clark et al., 2016)

Basis 2: marketing communications (company websites, e-mial-marketing, viral marketing).

Basis 3: interactivity (blogs, customer reviews, online communities).

Basis 4: content (search engine, site content, use of graphics and visualization).

Thus, branding is formed from two components: the brand of the product and the brand of the enterprise. From the point of view of management, the branding strategy includes internal factors of enterprise management such as brand-oriented organizational structure, interoperability of units, joint partnerships. Depending on the corporate structure, the brand can be profit-oriented or market-oriented. From a marketing perspective, branding is closelylinked to the development of integrated marketing communications that reflect brand significance, effectiveness, image, brand judgment, and the emotions it evokes (Bell et al., 2004).

For a modern company, brand is an important intangible asset. Its effective management can increase not only the company's profits but also the level of competitiveness. However, a brand, like any other asset, requires not only management but, above all, analysis and evaluation for the proper allocation of available resources.

No branding concept is unique in that it has both advantages and disadvantages, so it is necessary to determine the objectivity of brand evaluation methods.
Nowadays, there is a large number of methods estimating the value of a brand. The most common method is a cost method. Its essence is to present the brand as the sum of the costs of its creation, positioning, advertising promotion and continuous development (Geyer, 2006). The use of data on available costs, known directly to the company, is a significant advantage of this method. On the other hand, there are difficulties in applying it to the brands that have been successful in the market for several decades and definition of specific marketing and advertising costs.

The next is a market method which compares brand sales in the market, i.e. difference between the accounting and market value of the brand (Zborovsky, 2018). However, there are difficulties in determining the real market value of the company, as well as the presence of different brand values for certain categories of consumers. This method does not take into account different brand value for certain categories of consumers.

Revenue method is to assess what income can bring this brand in the future. The disadvantages are the difficulty in forecasting the additional revenue that the company's brand will bring in the long run.

The royalty-based method determines the amount to be paid if the trademark rights belonged to another company. This amount is determined by discounting. The value of the royalty rate is determined by experts, but there are shortcomings 
in determining the real price of the brand. Only transactions for its purchase and sale can determine this price (Kobelev, 2018).

The economic method is used to assess the brand's investment in business over the past few years, taking into account market stability of the enterprise. The disadvantage of this method is the weak link between past income and future.

The method of total discounted added value, i.e, determining the amount by which the value of the goods increases. It is calculated as the difference between a branded product and a similar nonbranded way by subtracting the brand's costs from profit and multiplying them by the estimated sales volume during the life cycle of the brand (Pyatak, 2013).

Interbrand model is a method of estimating the value of a brand, based on net present value. It consists of four successive stages. In the first stage, the cash flow generated by intangible assets is calculated by deducting the amount of investment capital and the rate of return on net operating profit of the enterprise. The next step is to assess the brand's role in cash flow, i.e. the degree of influence of the brand on key indicators in percent. The third stage involves calculating the discount rate by determining the brand strength index, analyzing certain indicators (leadership, stability, market, internationality, trend, support, legal protection). Then the brand multiplier is determined, using an $\mathrm{S}$-shaped curve. The last stage is calculation of the brand's value by the product of cash flow and brand multiplier (Kholodnyi, 2014).

As for the bakery industry, at this time it is one of the most attractive sectors of the food industry for investment. Uninterrupted provision of bread and bakery products to the population is one of the components of support at the appropriate level of state food security. Thus, increasing competitiveness of enterprises in the industry, their development, creation and expansion of strong brands is one of the main tasks for producers.

Bakery industry of Ukraine is represented by a wide network of domestic bakeries, supplying the population with bread. To determine the value of the brand, we choose one of the leading companies in the bakery industry, located in the city of Kyiv - "Kyivkhlib". The calculation was carried out, using a combination of "Interbrand Model" methods and the royalty method based on the company's public reporting data for 2019. Analysis of the main performance indicators of the enterprise to assess the value of the brand, is presented in Table 2.

The index of the brand's role was calculated by an expert method, using seven main criteria. "Kyivkhlib" occupies one of the leading positions in the market of the baking industry in Ukraine, so a leadership criterion has 24 points. Stability has 13 points. Buyers trust the company's brands not only in the city of Kyiv but also in the country as a whole. Market has 9 points, the bread market is steadily growing, being the most attractive for investment. Internationality (or geography) has 18 points, the company is widely recognized not only in the country but also abroad. Tendencies (or trends) have 8 points, the company's brands steadily increase in sales from year to year. Support has 9 points, the company has financial support in the form of investments. Protection has 5 points,

Table 2

Analysis of financial results of "Kyivhlib" for 2019

\begin{tabular}{|c|l|c|}
\hline$№$ & \multicolumn{1}{|c|}{ Index } & 2019 \\
\hline 1 & Net income from the sale of bakery products, thousand UAH & 2619582 \\
\hline 2 & Variable costs, thousand UAH & 819590 \\
\hline 3 & The cost of goods sold & 51972730 \\
\hline 4 & Fixed costs, thousand UAH & 24,8 \\
\hline 5 & Share of variable costs in the cost structure, \% & 15,7 \\
\hline 6 & Share of fixed costs in the cost structure, \% & 628726 \\
\hline 7 & Marketing costs & 19,0 \\
\hline 8 & Share of marketing costs in the overall cost structure, \% & 2697 \\
\hline 9 & Profit before tax, thousand UAH & 544 \\
\hline 10 & Taxes, deductions, thousand UAH & 2153 \\
\hline 11 & Net operating profit after taxes, thousand UAH & 14688 \\
\hline 12 & Number of assets of the enterprise (fixed assets and working capital), thousand UAH & 4455 \\
\hline 13 & Depreciation deductions, thousand UAH & \\
\hline
\end{tabular}

Source: according to the financial statements of "Kyivhlib" (2019) 
the company is legally registered and protected at the state level. Thus, the brand role index is $86 \%$ (Table 3).

Table 3

Calculation of the brand multiplier of "Kyivhlib"

\begin{tabular}{|c|l|c|c|}
\hline № & $\begin{array}{c}\text { Indicators of } \\
\text { brand strength }\end{array}$ & $\begin{array}{c}\text { Maximum } \\
\text { point, }(\%)\end{array}$ & $\begin{array}{c}\text { "Kyivkhlib», } \\
(\%)\end{array}$ \\
\hline 1. & Leadership & 25 & 24 \\
\hline 2. & Stability & 15 & 13 \\
\hline 3. & Market & 10 & 9 \\
\hline 4. & Internationality & 25 & 18 \\
\hline 5. & Tendencies & 10 & 8 \\
\hline 6. & Support & 10 & 9 \\
\hline 7. & Protection & 5 & 5 \\
\hline 8. & Total & 100 & 86 \\
\hline
\end{tabular}

Source : according to the financial statements of "Kyivhlib"

Interbrand has developed its own S-shaped curve, which shows the relationship between the discount rate (x-axis) and the brand strength index (y-axis) (Geyer, 2006). The discount rate of the ideal brand (100 points) is 5\%, which corresponds to the longterm return on risk-free investments. The average brand with a strength index of 50 has a discount rate of about $15 \%$. As for "Kyivkhlib", it has been determined that the score of the brand ( 86 points) corresponds to the value of the brand multiplier 18.8 (Figure 1).

The last stage is the direct calculation of the final value of the brand, the indicators of which are shown in Table 3 . The brand profit is defined as the product of the amount of profit from the intangibles and the index of the brand's role.

To calculate the discount rates (Dr) of cash flows over the years of the investment economic life,we used the formula:

$$
D r=\frac{1}{\left(1+\frac{D r}{100}\right)^{i-1}}
$$

where $D r$ - discount rate, \%;

$i$ - year, on which the discount rate is calculated (Petriv, 2017).

Net discounted cash flow is calculated as the product of net cash flow value (brand profit) and the discount rate.

The cost of the brand is calculated by the formula:

$$
B V=D \times \text { multiplier }
$$

where $B V$ - company's brand value;

$D$ - cash flow from NMA;

multiplier - brand-multiplier.

Table 4

\section{Indicators of "Kyivhlib" for calculating}

the brand value

\begin{tabular}{|c|l|c|}
\hline № & \multicolumn{1}{|c|}{ Indicator } & Estimated data \\
\hline 1. & $\begin{array}{l}\text { Income from intangible assets, } \\
\text { thousand UAH }\end{array}$ & 5871 \\
\hline 2. & Brand role index, \% & 85 \\
\hline 3. & Discount rate, \% & 18,8 \\
\hline 4. & Discount coefficient & 0,842 \\
\hline 5. & Brand profit, thousand UAH & 5049 \\
\hline 6. & $\begin{array}{l}\text { Net discounted cash flow, } \\
\text { UAH thousand }\end{array}$ & 4251,3 \\
\hline 7. & $\begin{array}{l}\text { Final cost of the brand, } \\
\text { UAH thousand }\end{array}$ & 5093,1 \\
\hline
\end{tabular}

Source: developed by the authors

The results (Table 4), obtained using the method based on the Interbrand model, show that the value of "Kyivkhlib" brand is at the level of 5093.1 thousand UAH. Due to the fact that this model involves many subjective estimates, they

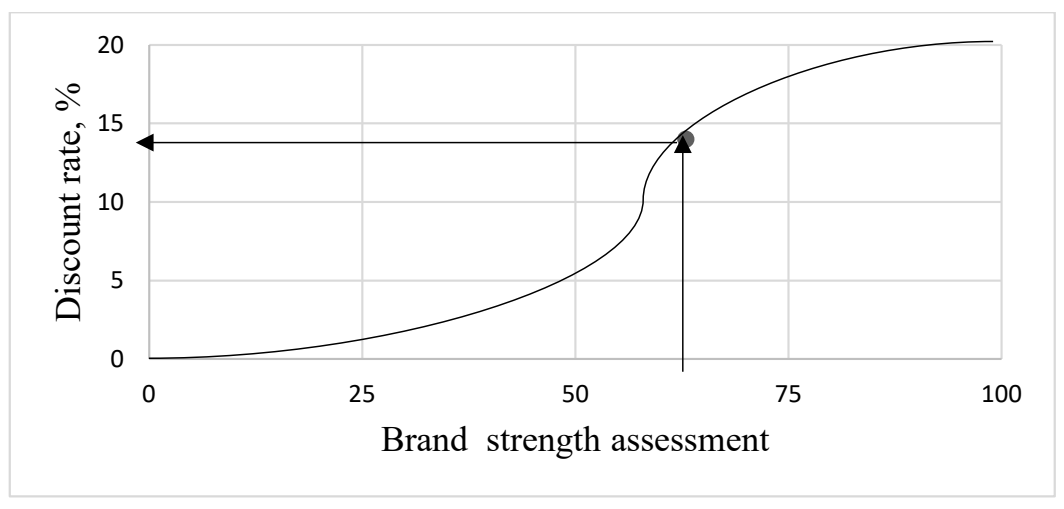

Figure 1. S-shaped curve that reflects the relationship between the brand multiplier and the brand strength index 
may differ from the calculations obtained by using other methods and models.

The authors have also developed a complex of marketing communications for a period of three years. The purpose of the strategic plan is to promote the innovative line of bakery products of "Kyivkhlib". The first stage is to create a promotional calendar for internal demonstration of the planned activities for the target audience.

The process of a promo calendar formation has a number of features:

- mandatory registration of all weeks on the days of the selected marketing period. In our case - for 2021;

- fixing all holidays and solemn actions to which it is possible to bring the advertising campaign of the manufacturer and to stimulate sale of dairy products;

- fixing the exact period of receiving wages of consumers. According to the research, a person spends the most money in the first week after receiving a salary. This is especially true for women who have children and receive social benefits. It will be appropriate to stimulate the sale of products - to hold tastings, organize themed shop windows, photo areas, but not the pricing methods of selling goods;

- advertising events are selected. In our case: publication of product catalogues (3 times a year), advertising and information posts on the company's website and social media pages "Instagram", "Facebook"; placement of quality material on photo ("Pinterest") and video hosting ("YouTube"), active participation in exhibitions and fairs; "E-mail" - mailing;

- demonstration areas of advertising activities and tools of marketing communications of the enterprise are highlighted, as well as its biggest competitors and intermediaries.

Table 5 shows the promotional calendar for the first quarter for the planned 2022 marketing year. January begins immediately with the Christmas holidays, so it is appropriate to be prepared in the 4th quarter of the previous marketing year. The process of planning communication activities of competitors is based on the analysis of the research results for the previous period. As you can see, Competitor 1 posts information in the social network Instagram every week, but no more than 2 times a month in Facebook. Competitor 2 plans its communication activities in a similar way, so this situation allows of "Kyivkhlib" to develop implementation stages of its own marketing communication plan more efficiently and in accordance with the requests of the target audience.

It is with the help of such narrowly focused means of marketing communications as E-mail mailing that we give maximum information about the brand, manufacturers and product range of the company to our target customers and partners. Therefore, the articles to be published in magazines each month and the catalogue of goods, acquainting the consumers with new products, will be distributed through the CRM-system at the enterprise for additional informational promotion. Articles in magazines will acquaint readers with new trends in the baking industry and development of innovative technologies for the production of organic and safe food.

Tasting in the first quarter is scheduled for 5th week, a few days before the holiday. Getting to know a new product early, allows consumers to learn more about an unfamiliar product, taste it, and next time choose a product that is familiar and loyal to the customer, thus increasing its sales on holidays. Participation in exhibitions and fairs at the end of January will help revive demand for products after the most costly period of the New Year and Christmas holidays, during which the population's financial opportunities to purchase even basic necessities are sharply reduced.

During such PR-campaigns it is also possible to acquaint the target audience with the brand of bakery products of "Kyivkhlib", to dispel myths about the harmfulness of products made of certain types of flour and get feedback on the positive aspects and shortcomings of the brand, advertising company, product quality and possible new products.

To attract better brand promotion among young people, posts with quality content and professional photos and videos will be posted on corporate social media pages several times a month. In the future, it will be appropriate to integrate the brand with popular for the target audience entertaining and educational "YouTube" channels, culinary blogs and even collaboration with some professional bloggers-experts in the field of healthy eating and sports.

\section{Conclusion}

As already noted, under the current conditions of development of the world economy to assess the competitiveness of any company now and at 


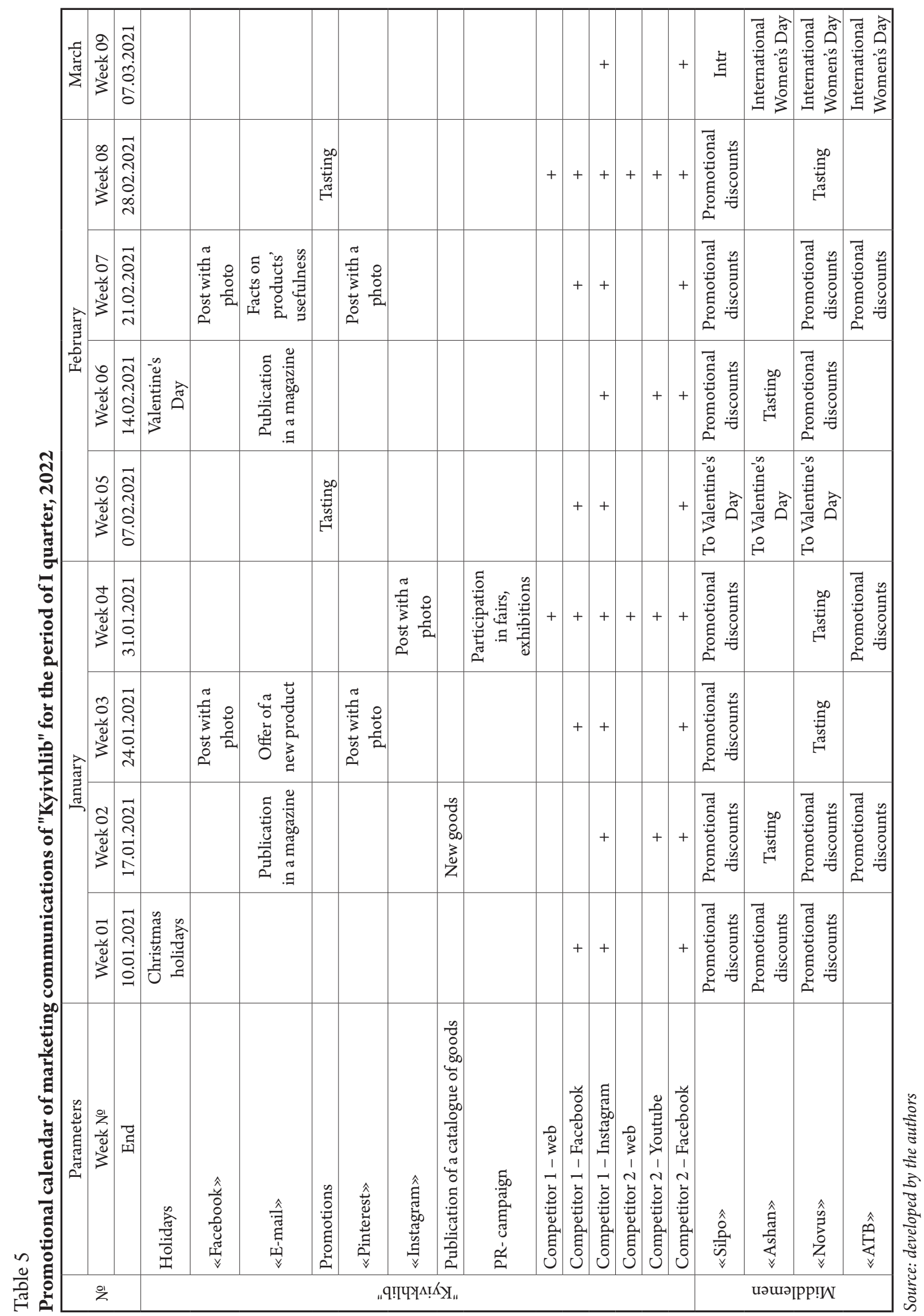


the expense of quantitative indicators, and the presence of a sufficiently strong and effective brand. The article considered two markets in Ukraine: the market of milk and dairy products for baby food and the market of bread and bakery products. The markets were considered in terms of marketing development and brand formation under the influence of such criteria as emotions, attributes, affiliation with the society, traditions, etc. The general statements concerning the theories of the brand development were analyzed by different scientists, scientists and economists and they came to the following conclusions: the brand identity is expressed in such aspects as the brandoriented culture, top-management support and the internal marketing orientation of the firm; the brand value is shown in the synergy (interactivity, constancy, complexity) and the effectiveness of the integrated marketing communications. Consequently, effective brand management is based on a coordinated program of integrated marketing communications.

It was also determined during the research that branding is formed from two components: the brand of the product and the brand of the enterprise, and it is also closely connected with the development of integrated marketing communications, which reflect the importance of the brand, the effectiveness of the brand, the image of the brand, the judgment about the brand and the emotions that the wine evokes.

It has been analyzed that bakery industry of Ukraine is represented by a wide network of domestic bakeries and bakeries, which provide the population with bread. To determine the brand value, one of the leading enterprises in the bakery industry, located in the city of Kyiv - "Kyivhlib", was chosen. The calculation was carried out using a combination of methods "Interbrand Model" and the method of royalty on the basis of the public statements of the enterprise for 2019. The index of the brand role was defined by expert method, using seven basic criteria (leadership, stability, market, internationality, trends, support, protection). As a result, the index of brand role added up to $86 \%$. As for "Kyivkhlib" it was determined that the brand-multiplier value of 18,8 corresponds to the point estimate of brand strength (86 points).

The results obtained by using the method based on the "Interbrand" model, showed that the brand value of "Kyivhlib" is at the level of 5093,1 thousand UAH. Due to the fact that this model involves a large number of subjective evaluations, the results may differ from the calculations obtained by using other methods and models. Also developed a plan of marketing communications complex for three years. The purpose of the strategic plan is to promote an innovative line of bakery products "Kyivhlib" and the first stage of the plan is the creation of promotional calendar for internal demonstration of the planned activities for the target audience. In this article the promotional calendar demonstrates only I quarter for 2022 marketing year and examples of planned marketing activities: E-mail, articles in magazines, printing and mailing catalog of products, conducting tastings, participation in exhibitions and fairs, as well as a clear plan of content presentation in social networks and videohosting.

The value of the brand affects both the financial aspects of the enterprise and its non-financial side. It is worth noting that the brand is an intangible asset but it provides a real financial result in the form of profit. That is why companies, seeking to gain a leading position in the market, should pay close attention to assessing the brand value and using the obtained data in strategic management.

\section{References:}

Bell, S., Mengüç, B., \& Stefani, S. (2004). When customers disappoint: A model of relational internal marketing and customer complaints. Journal of the academy of marketing science, 32(2), 112-126. DOI: https://doi.org/10.1177/0092070303261467

Hankinson, G. (2004). Relational network brands: Towards a conceptual model place brands. Journal of Vacation Marketing, 9, 127-142.

Geyer, G. V. (2006) Financial value of brands and methods of its estimation. University scientific notes, 3-4 (19-20), 469-475.

Gubesch, M., Theler, B., Dutta, M., Baumer, B., Mathis, A., \& Holzhauser, T. et al. (2007). Strategy for allergenicity assessment of natural novel foods: clinical and molecular investigation of exotic vegetables (water spinach, hyacinth bean and Ethiopian eggplant). Allergy, 62(11), 1243-1250. DOI: https://doi.org/10.1111/j.1398-9995.2007.01474.x 
Keller, K. L., \& Lehmann, D. (2009). Assessing brand potential. In Brand value and valuation, Special Issue, Journal of Brand Management 17, ed. R. Raggio and R. P. Leone, 6-7.

Keller, K. L., \& Lehmann, D. (2006). Brands and branding: Research findings and future priorities. Marketing Science, 25, 740-759.

Kholodnyi, G. O. (2014). Analysis of methodological approaches to valuing brands. Scientific Bulletin of Poltava University of Economics and Trade, 6, 164-172.

Kobelev, V. N. (2011). Economic evaluation of the brand in the context of assessing the value of the company's business. Bulletin of the National Technical University "Kharkiv Polytechnic Institute", 8, 53-57.

Kyivkhlib.ua. (2019). Retrieved 1 June 2021, from: https://kyivkhlib.ua/wp-content/uploads/2020/06/ fz-td-ki\%D1\%97vhlib-2019.pdf

Petriv, I. Y. (2017). Features of enterprises evaluation based on the method of discounting cash flows. Economic discourse, 2, 136-144.

Pyatak, T. V., \& Igumnova, V. O. (2013). Evaluation of the company's trademark (brand). Bulletin of NTU "KhPI", 24(997), 114-121

Reid, M. (2002). Building Strong Brands Through the Management of Integrated Marketing Communications. International Journal of Wine Marketing, 14(3), 37-52.

Seo, S., \& Jang, S.C.S. (2013). The roles of brand equity and branding strategy: A study of restaurant food crises. International Journal of Hospitality Management, 34, 192-201.

Stewart, D., \& Martin, I. (1994). Intended and Unintended Consequences of Warning Messages: A Review and Synthesis of Empirical Research. Journal Of Public Policy \& Marketing, 13(1), 1-19. DOI: https://doi.org/10.1177/074391569401300101

Walters, D., Halliday, M., \& Glaser, S. (2002). Added value, enterprise value and competitive advantage. Management Decision, 40(9), 823-833.

Zborovsky, R. V. (2018). Methods of brand evaluation. International scientific-practical conference. Priority directions of economic development: new realities and opportunities in the conditions of integration. Zaporizhzhia, 40-43. 